\title{
Dentingan Palu Tempa Pengarajin Pandai Besi Sungai Puar Mulai Sunyi
}

\author{
Armila \\ Teknik Mesin/Fakultas Teknik/ Universitas Muhammadiyah Sumatera Barat \\ Email:kimmylala74@gmail.com
}

\begin{abstract}
Abstrak: Nagari Sungai Puar adalah nagari dengan tanah yang subur terletak diantara dua gunung api, Merapi dan Singgalang. Masyarakat menggantungkan diri pada pertanian dan kerajinan pandai besi. Nagari ini sudah memproduksi alat-alat pertanian sejak zaman kolonial belanda. Banyaknya pandai besi yang menjadikan kegiatan tempa ini menjadi mata pencaharian. Akan tetapi seiring perkembangan pasar global tempa sungai puar mulai terkikis, karena terjadi perbedaan kualitas dan persaingan harga. Ketidakmampuan pengrajin dalam meningkatkan kualitas membuat industri ini mulai sepi dan mulai ditinggalkan. Produk China mulai banyak digunakan. Kurangnya transfer teknologi yang membuat pengrajin tidak mampu mengembangkan industri ini menjadi industri yang mempunyai daya saing dan dapat menjadi tuan rumah di nagari sendiri seperti dulu. Proses tempa yang dilakukan secara manual membuat proses produksi rendah dan kualitas produk kurang bagus, serta proses pengerasan logam yang dilakukan tidak sesuai dengan kaidah metalurgi menyebabkan produk kurang kuat dan daya tahan terhadap korosi rendah.
\end{abstract}

Kata kunci: pandai besi, tempa, pengerasan logam, pasar global,korosi.

Abstract: Sungai Puar Village placed between two mountain Merapi and singgalang. Most people in this village depend on agriculture $n$ blacksmith. Blcksmith based on from nederland colonial and they depend income with this. Along with market global, where china product more taft and chip. But here people doing forging process still manualy, they used forged hammer by hand, which are caused low production and high cost. Strain hardening process not allowing metalurgy rules, so product not only bad but also not resistance for corrosion. People here less knowledge about material tecnology, every step process still in tradisional, no machining, no material tecnology rules makes product be left.

Keyword: Blacksmith, forging, strain hardening, global market, corrosion.

\section{PENDAHULUAN}

\subsection{Latar Belakang}

Nagari Sungai Puar terletak diantara dua gunung api aktif Gunung Merapi dan Gunung Singgalang, kondisi Nagari ini sangat subur. Hampir $85 \%$ penduduk nagari ini menggantungkan pendapatan keluarga dari pertanian. Dimana lebih dari $90 \%$ produk pertanian tradisional dibuat sendiri oleh penduduk setempat, yang digunakan oleh petani-petani dari desa-desa sekitar atau lintas kabupaten/bahkan secara lokal untuk petani Sumatera Barat. Nagari Sungai Puar sangat terkenal dengan usaha pandai besi yang telah ada sejak zaman kolonial Belanda, Ditandai dengan adanya tungku KUPOLA PELEBURAN dan PENGECORAN KUNO besi/baja dan kuningan yang masih bisa digunakan.
Akan tetapi seiring perkembangan teknologi dan dibuka pasar bebas global, membuat produk lokal kurang diminati, adanya persaingan harga dan kualitas yang membuat pergeseran orientasi masyarakat dalam membeli produk.

Pada hakikatnya produk lokal Nagari Sungai Puar dapat ditingkatkan dengan menggunakan TEKNOLOGI MATERIAL atau MATERIAL TREATMENT, akan tetapi sedikit sekali para instansi pendidikan lokal yang menulis tentang perbaikan kualitas logam dan jarangnya perguruan tinggi setempat yang fokus terhadap peningkatan kualitas mutu logam yang dihasilkan.

Peningkatan kualitas logam/alat-alat pertanian ini terhitung sederhana dan dapat dilakukan secara manual dengan biaya yang 
murah, akan tetapi keterbatasan transfer teknologi yang membuat industri ini makin hari semakin ditinggalkan oleh penduduk setempat.

Produk pertanian yang dihasilkan nagari ini berupa cangkul, sabit, parang, pisau, linggis, sekop, bajak dan produk kuningan.

Karena lingkup pertanian setempat masih tradisional maka alat-alat pertanian pun masih menggunakan yang tradisional. Akan tetapi saat ini masyarakat banyak menggunakan produk pertanian buatan China, dimana harga lebih murah, ringan dan kuat. Pada dasarnya produk China ini tidak terlalu bagus hanya saja mereka memberikan harga yang murah, kalau dilihat dari kualitas logamnya termasuk kedalam baja karbon rendah bahkan ada yang terbuat dari Aluminium paduan/alloys, akan tetapi penerapan teknologi pengerasan logam, dan ketahanan korosi/karat yang disertai dengan finishing yang baik, membuat produk mereka lebih awet dalam penggunaan.

Melihat kondisi ini saya sebagai lulusan Teknik Metalurgi merasa terpanggil untuk membuat sebuah perubahan dengan membuat sebuah kajian khusus yang nantinya dapat memberikan pengarahan atau penyuluhan tentang teknologi-teknologi yang mampu meningkatkan kualitas produk logam untuk pertanian dan rumah tangga. Selain teknologi pengerasan logam juga akan saya jelaskan tentang perlindungan terhadap logam sehingga produk yang dihasilkan tidak saja kuat akan tetapi tahan terhadap karat/korosi.

Kondisi ini membuat saya sangat ingin membuat sebuah buletin khusus yang memuat tentang teknologi-teknologi tentang Material Treatment pada logam, yang nantinya sangat bermanfaat bagi masyarakat luas terutama Nagari Sungai Puar karena ini sangat berdekatan dengan lingkungan kegiatan perguruan tinggi setempat. Tulisan ini merupakan langkah awal dari sebuah road map penelitian yang sudah saya siapkan.

\subsection{Tujuan Kegiatan}

Penelitian ini merupakan suatu langkah awal dari rangkaian tulisan yang berkesinambungan yang memuat teknologiteknologi pengerasan logam dan perlindungan logam, serta finishing yang tepat untuk berbagai macam produk yang dihasilkan oleh pengrajin pandai besi, dalam pembuatan produk alat-alat pertanian dan rumah tangga. Pemilihan pegas daun dan sasis kendaraan sebagai bahan baku sudah tepat, hanya saja proses pembentukan logam dan pengerasan logam yang masih kurang tepat.

Para pengrajin pandai besi umumnya mendapatkan bahan baku dari penggumpul besi tua. Produk ini akan sangat bagus dan mempunyai daya saing yang baik kalau proses pembentukan logam dan material treatment yang dikukan adalah tepat, karena bahan baku produk merupakan baja karbon sedang yang mempunyai titik lebur yang tinggi dan kadar karbon yang sangat baik untuk dapat dilakukan proses pengerasan logam. Untuk itu kajian ini sangat diharapkan dapat menjadi suatu langkah awal perubahan metoda proses produksi yang baik dalam pembuatan alat-alat pertanian tradisional.

\subsection{Tinjauan Pustaka}

Proses pembuatan alat-alat pertanian dari pegas daun secara tradisional dikenal dengan proses TEMPA/FORGING, proses ini melibatkan temperatur/suhu tinggi dalam proses pembentukan logam, biasa disebut dengan proses pembentukan logam secara hot working. Berikut ini landasan teori tentang proses tempa yang relevan dengan proses yang dilakukan oleh pengrajin pandai besi.

\subsubsection{Tempa/Forging}

Tempa adalah proses pengerjaan logam menjadi suatu bentuk yang diinginkan dengan menggunakan palu atau penekan. Dan merupakan proses pengerjaan logam yang paling tua. Sebagian besar pompa dikerjakan pada temperatur panas. Tempa dikategorikan kedalam dua kelompok yaitu:

- Tempa terbuka (open die forging)

- Tempa tertutup (closed die forging)

Tempa terbuka biasanya digunakan pada pembuatan awal produk kemudian dilanjutkan dengan tempa tertutup. Tempa terbuka yang paling sederhana adalah upsetting yaitu bongkah silinder diantara dua pelat datar. 
Peralatan tempa yang paling banyak digunakan adalah mesin palu, mesin ini dikenal dengan dua macam antara lain:

- Palu papan (board hammer)

- Palu daya ( power hammer)

Pada palu papan (board hammer) cetakan atas dan penumbuk dinaikkan oleh rol gesek yang mencekeram papan, apabila papan dilepaskan, penumbuk akan jatuh karena gaya gravitasi dan menghasilkan energi tempa, kemudian papan akan segera dinaikkan untuk penempaan berikutnya, biasanya dilakukan berulang-ulang 60-150 x setiap menit.

Energi yang diberikan oleh tumbukan sama dengan energi potensial berat penumbuk pada tinggi jatuh tertentu.

Kemampuan tempa yang lebih besar dicapai dengan menggunakan palu daya, disini penumbuk dipercepat, saat langkah bawah oleh uap atau tekanan udara di samping gaya gravivitasi . uap atau udara juga digunakan untuk mengangkat penumbuk pada waktu langkah atas.

Energi total yang diberikan oleh palu pada saat tempa adalah:

$$
W=\frac{1}{2} \frac{m v 2}{g}+p A H=(m p A) H
$$

Dimana:

$\mathrm{m}=$ berat penumbuk

$\mathrm{v}=$ kec. Penumbuk

$\mathrm{g}=$ kecepatan gravitasi, 32,2 ft/dt

$\mathrm{p}=$ tekanan udara atau uap yang bekerja pada silinder penumbuk pada langkah kebawah

$\mathrm{A}=$ luas silinder penumbuk

$\mathrm{H}=$ tinggi kejatuhan penumbuk

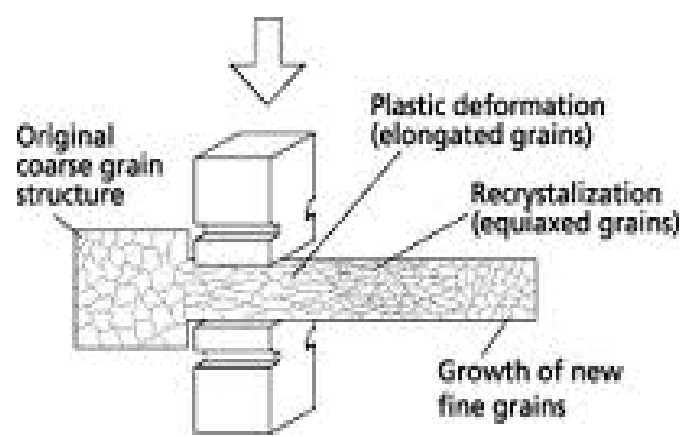

Gambar 1.1 Gambar Proses Tempa
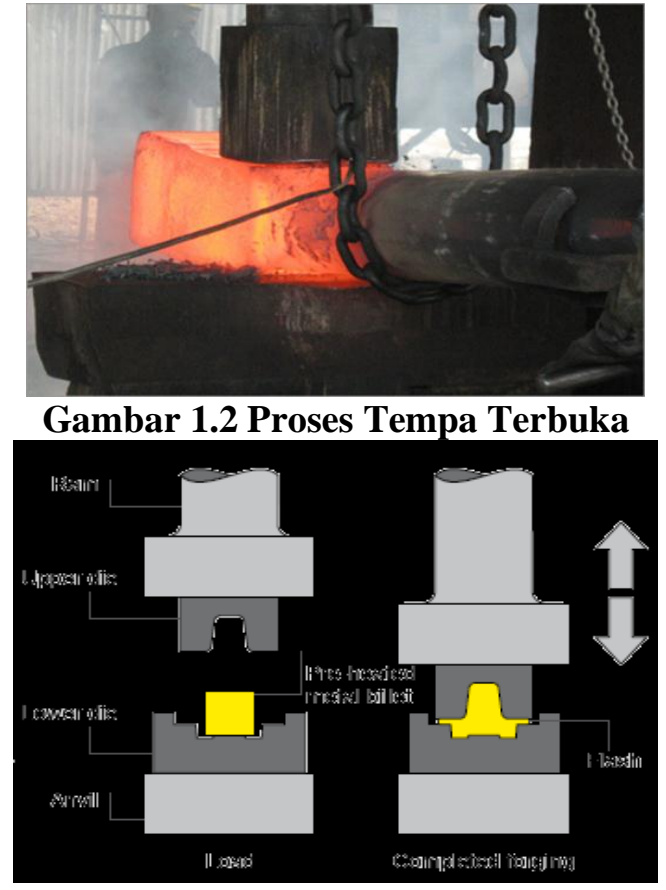

Gambar 1.3 Skema Proses Tempa

Tertutup

\subsubsection{Proses Strain}

Hardening/Penyepuhan

Proses Strain Hardening adalah sebuah proses perlakuan panas yang memberikan efek keras pada material logam, proses ini bertujuan menambah kekerasan logam sehingga saat penggunaan logam akan tahan terhadap beban kejut dan tumbukan. Kondisi pemakaian dilapangan terkadang sangat tidak terduga sehingga harus dilakukan heat treatment yang dapat menaikkan angka kekerasan material logam hasil proses forging.

Kalau dilapangan proses ini disebut dengan proses penyepuhan, dimana material yang telah selesai ditempa, kemudian dipanaskan kembali dan dicelupkan ke dalam air dingin. Berikut ini grafik proses yang menjelaskan mekanisme pengerasan yang dilakukan, dimana media pendingin bisa berupa air, oli, udara, air dingin dan tungku. Pendinginan yang cepat menghasilkan struktur martensit yang menyebabkan baja menjadi keras inilah yang disebut dengan fenomena strain hardening. 


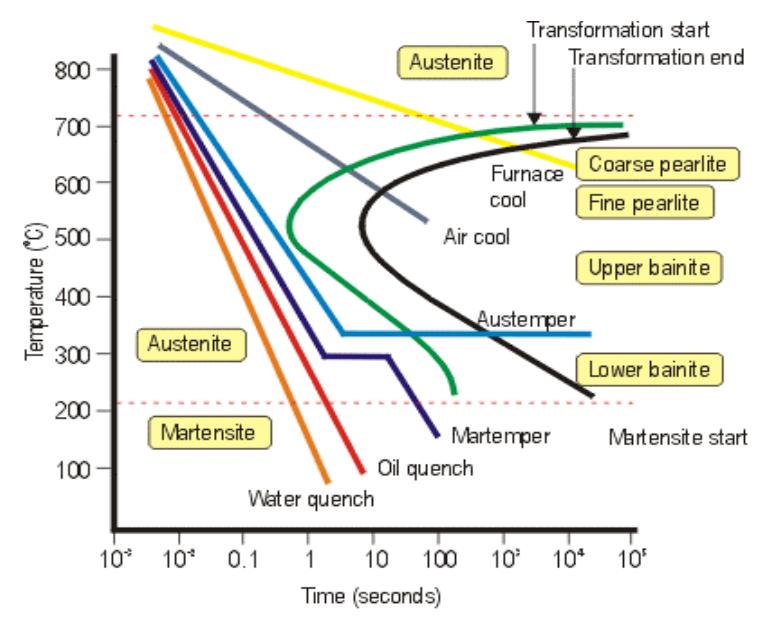

Gambar 1.4 Proses Heat Treatment Logam

\section{METODOLOGI PENELITIAN \\ 2.1 Diagram Alir Penelitian}

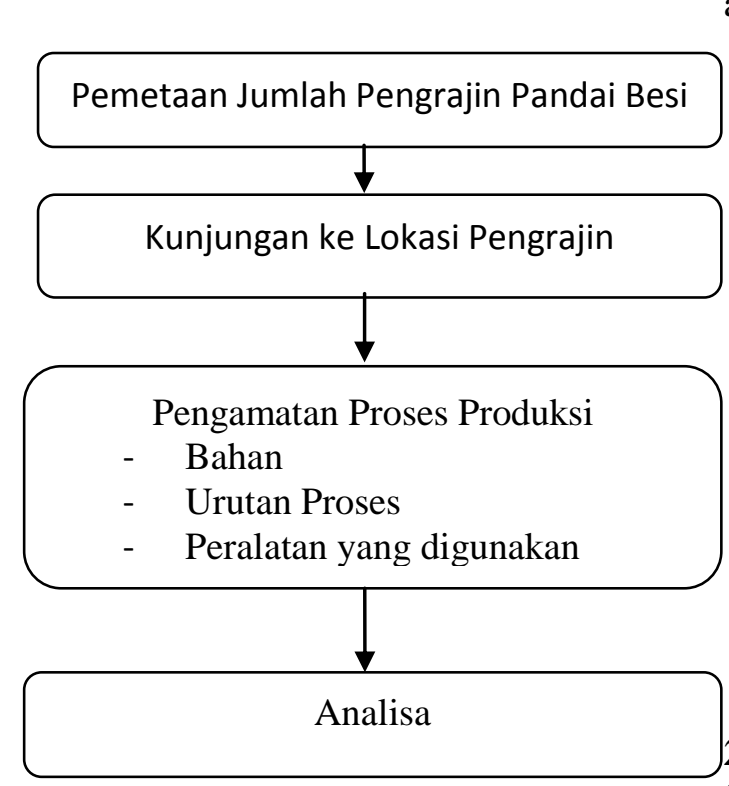

Gambar 2.1 Diagram Alir Penelitian

2.2 Pemetaan Lokasi Pengrajin

Nagari Sungai Terletak diantara dua Gunung api aktif Merapi dan Singgalang, Pengrajin pandai besi tersebar dibeberapa Jorong antara lain jorong Bukik Batabuah (terdiri dari beberapa spot), Jorong Sariak (terdiri dari beberapa spot)

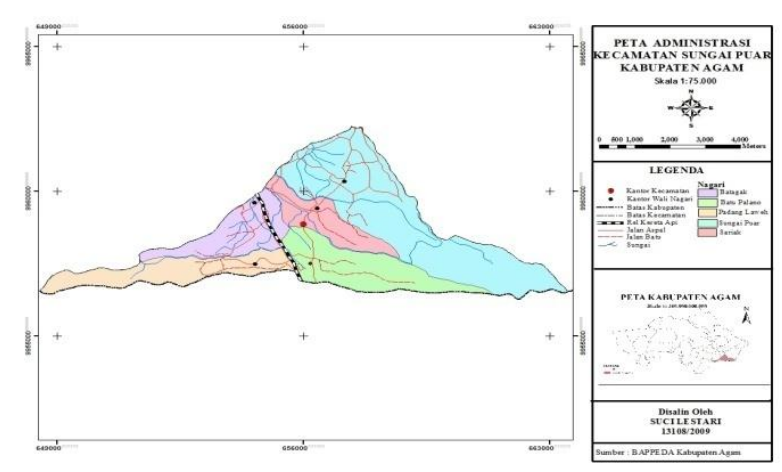

Gambar 2.2 Peta Lokasi penyebaran Pengrajin Pandai Besi

\subsection{Kunjungan Ke Lokasi Pengrajin}

Lokasi yang kami kunjungi bersama mahasiswa adalah Jorong Batabuah Ateh, dimana disana terdapat sekitar 10 pengrajin pandai besi, salah satu yang kami kunjungi adalah Bapak Nasrul dan Bapak Bandaro.

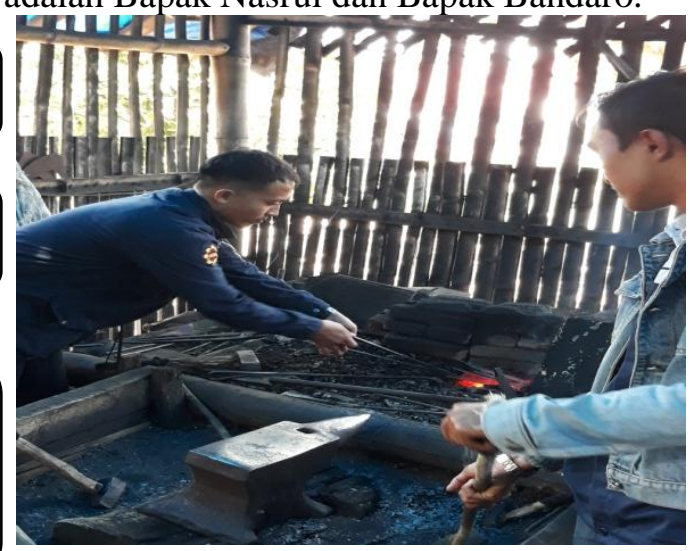

Gambar 2.3 Kunjungan Ke Lokasi Pengrajin

\subsection{Pengamatan Proses Produksi}

\subsubsection{Bahan Baku/Material}

Bahan pembuatan alat-alat pertanian ini umumnya pegas daun bekas atau sasis kendaraan.

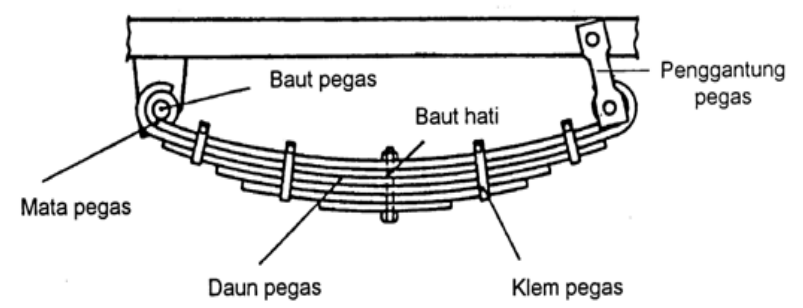

Gambar 2.4 Pegas Mobil yang dijadikan bahan baku 


\subsubsection{Tungku Pembakaran}

Proses pembakaran atau pemanasan logam dilakukan dengan membakar bahan baku diatas tungku dengan bahan bakar batu bara, temperatur pembakaran tidak ditentukan secara tepat hanya melihat perubahan warna logam saja, sampai logam berwarna merah nyala

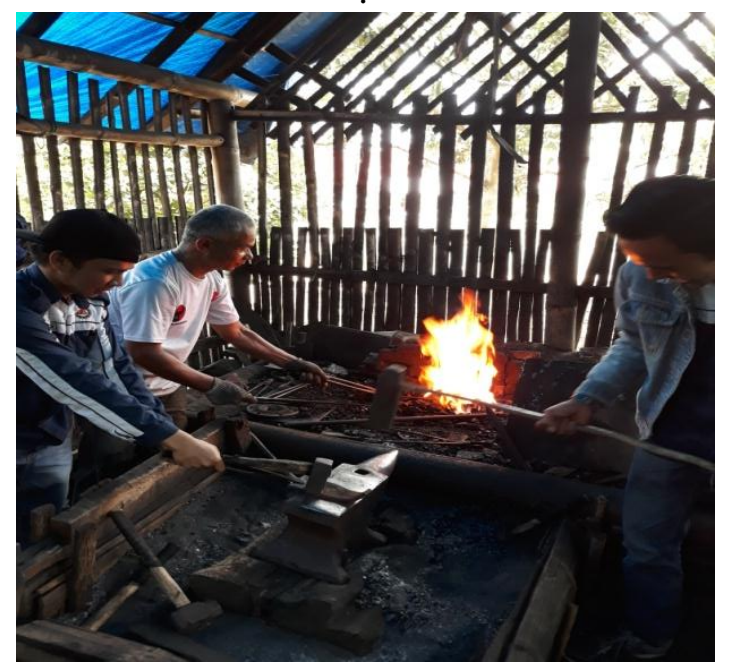

Gambar 2.5 Tungku Pembakaran

\subsubsection{Proses Tempa}

Proses tempa dilakukan oleh 2 orang, orang pertama menjepit dan mengarahkan proses pembentukan, sedangkan orang ke dua sebagai eksekutor palu tempa, dan proses harus dilakukan dengan ritme dan irama ayunan tempa yang benar. Sehingga proses pembentukan logam dapat berlangsung cepat dan mudah.

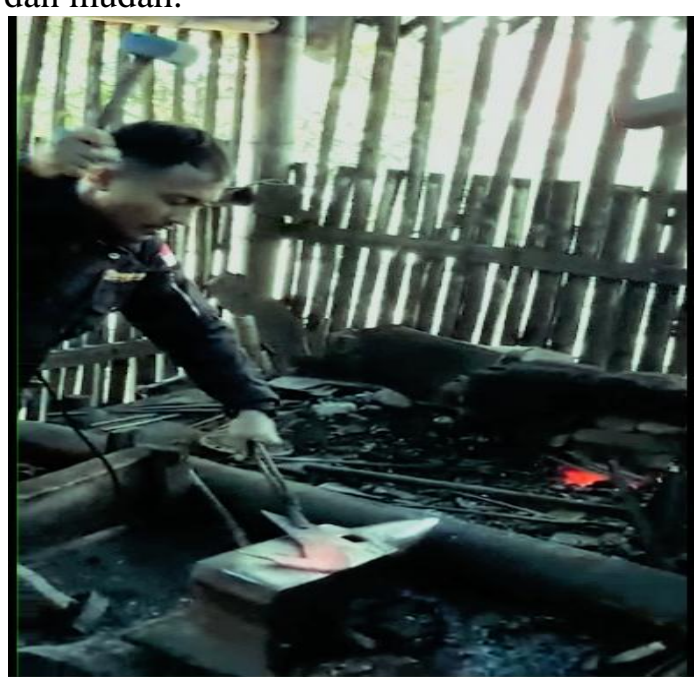

Gambar 2.6 Proses Tempa/Forging

\subsubsection{Proses Strain Hardening (Quenching} Water)

Setelah produk logam selesai ditempa, maka selanjutnya dilakukan proses penyepuhan, atau proses strain hardening, yang bertujuan mengeraskan logam setelah proses pembentukan secara di tempa. Proses ini sangat sederhana yaitu logam yang sudah ditempa dipanaskan kembali sampai warna merah menyala kemudian dicelupkan kedalam air dingin. Para pengrajin mengukur suhu hanya berdasarkan warna dari logam.

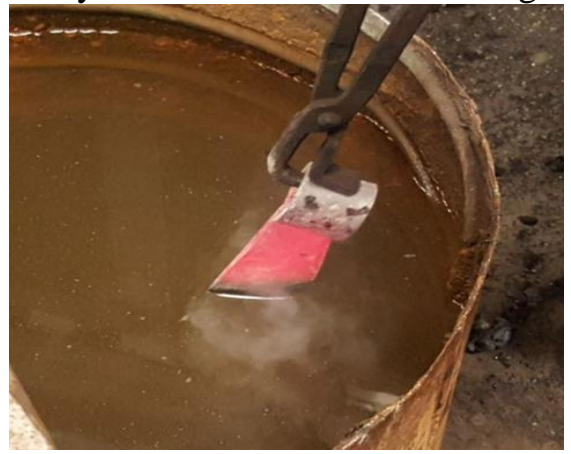

Gambar 2.7 Proses celup cepat dengan media air

\subsubsection{Proses Penggerindaan}

Penggerindaan merupakan proses fininshing yang bertujuan untuk menajamkan logam dan merapikan bagian-bagian yang kurang tepat pada proses sebelumnya.

Penggerindaan biasanya dilanjutkan dengan proses pengkiran pada bagian-bagian tertentu.

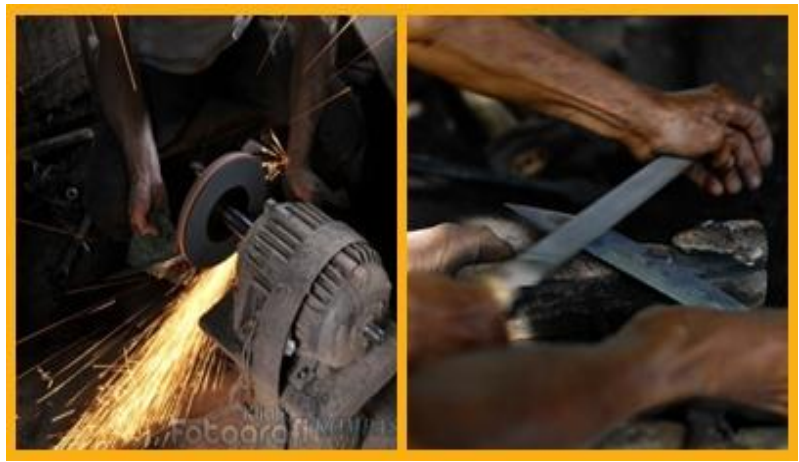

Gambar 2.8 Proses Penggerindaan

\subsubsection{Produk}

Produk yang dihasilkan oleh pengrajin pandai besi selain berupa alat-alat pertaian juga berupa alat-alat rumah tangga. 


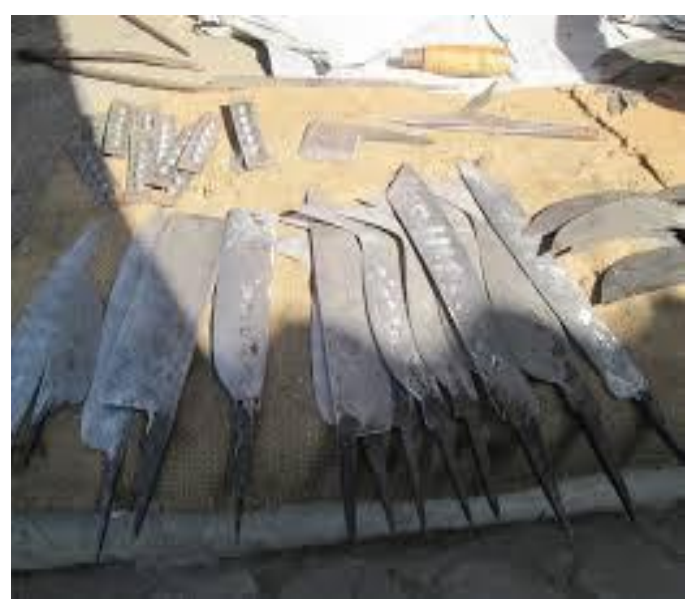

Gambar 2.9 Produk hasil proses tempa

\section{HASIL DAN PEMBAHASAN}

Produk yang dihasilkan oleh pengrajin besi Nagari Sungai Puar ini, bisa dikatakan lumayan bagus, hanya saja gempuran produk China yang lebih bagus bentuknya dan lebih murah harganya, membuat pengrajin banyak yang beralih profesi kembali kepada pertanian dan perkebunan.

Sebenarnya dari awal pemilihan bahan sampai produk banyak terjadi ketimpangan dan kesalahan dalam menghasilkan produk, hal ini tidak terlepas dari ketidaktahuan masyarakat pengrajin tentang bagaimana proses pembentukan logam yang tepat yang dapat menghasilkan produk yang kuat, bagus, tangguh dan tahan karat. Beberapa hal yang sangat perlu untuk dianalisis antara lain:

\section{Pemilihan Bahan}

Dalam pemilihan bahan saya lihat sifatnya untung-untungan adakalanya mereka mendapatkan pegas yang masih bagus untuk diproduksi tetapi terkadang pegas tersebut sudah tidak bisa di reproduksi, hanya saja kurangnya pengetahuan tentang bagaimana melihat material logam secara benar membuat mereka memproduksi saja setiap pegas tersebut menjadi cangkul, parang, sabit dan pisau. Dari pengamatan saya, saya melihat ada beberapa pegas tersebut yang sudah mulai terjadi korosi celah, bahkan sudah terdapat crack-crack halus, seharusnya material dengan kondisi ini sudah tidak bisa diproduksi, hanya bisa dilebur ulang, karena pegas fungsinya adalah meredam getaran membuat material ini sering menerima beban tumbukan, yang membuat material mengalami fatique, seharusnya material yang mengalami fatique ini sebelum diproduksi harus dilakukan proses Tempering terlebih dahulu untuk mengembalikan sifat fisik awal logam sebelum dilakukan proses pembentukan secara tempa. Proses tempering tidak sulit hanya memanaskan material sampai temperatur Austenit ( $($ ) kemudian biarkan dingin diudara, atau dibiarkan ditungku dan tungku dipadamkan, tetapi terbatas pengetahuan membuat semua terasa sulit.

\section{Proses Pembakaran}

Proses pembakaran yang bertujuan untuk melunakkan logam harus dilakukan secara tepat, pengrajin hanya mengandalkan perubahan visual logam saja, saat logam sudah berubah warna menjadi merah nyala maka logam siap untuk ditempa. Seharusnya proses tempa yang tepat dilakukan adalah pada temperatur Austenit, tergantung dari jenis material, karena yang dipakai pegas daun kendaraan, dimana material pegas adalah baja karbon sedang yang kadar karbon dalam kisaran $0.4-0.7 \%$ C.

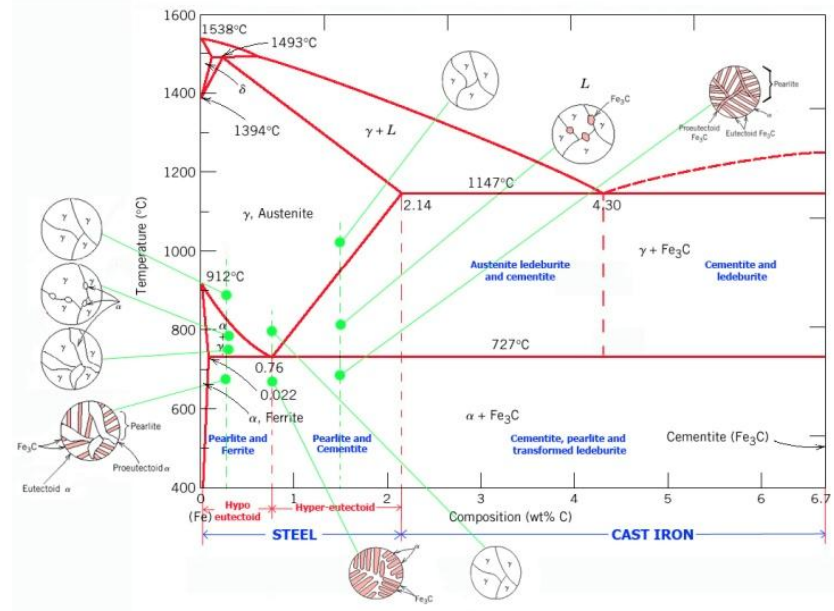

Gambar 3.1 Diafram Fasa Fe-Fe $\mathrm{F}_{3} \mathrm{C}$

Berdasarkan diagram fasa pemanasan untuk proses pembentukan adalah jika kadar karbon $0.7 \% \mathrm{C}$ adalah sekitar 850-900 ${ }^{\circ} \mathrm{C}$. Akan tetapi kenyataan dilapangan mereka hanya mengira-ngira saja sesuai dengan perubahan warna, seharusnya pada proses pembakaran dilengkapi dengan termokopel manual, sehingga temperatur pengerjaan tepat dan tentu hasil akan bagus. Ketepatan 
temperatur pengerjaan membuat struktur mikro seragam sebelum pembentukan dan proses mudah.

\section{Proses Tempa}

Proses tempa merupakan proses utama, berhasil atau tidaknya proses ini sangat bergantung kepada proses pemanasan logam sebelumnya, proses tempa termasuk kedalam proses pengerjaan panas, artinya sebelum ditempa material sudah dalam keadaan seragam struktur mikronya, maka selalu harus pada temparatur Austenit, selain itu eksekusi penempaan yang manual membuat proses tempa tidak mendapatkan gaya yang seragam disetiap permukaan. Energi yang diberikan oleh tumbukan sama dengan energi potensial berat penumbuk pada tinggi jatuh tertentu. Kemampuan tempa yang lebih besar dicapai dengan menggunakan palu daya, karena palu daya adalah tenaga manusia, disinilah terdapat banyak error. Karena Energi total yang diberikan oleh palu pada saat tempa adalah:

$$
W=\frac{1}{2} \frac{m v 2}{g}+p A H=(m p A) H
$$

$$
\begin{aligned}
& \begin{array}{l}
\text { Sementara penumbuknya adalah } \\
\text { manusia/orang }
\end{array} \\
& \text { Dimana: } \\
& \mathrm{m}=\text { berat penumbuk (tetap) } \\
& \mathrm{v}= \text { kec. Penumbuk (tidak tetap tergantung } \\
& \text { tenaga orang yang bekerja) } \\
& \mathrm{g}= \text { kecepatan gravitasi, } 32,2 \mathrm{ft} / \mathrm{dt}(\text { tetap) } \\
& \mathrm{p}= \text { tekanan berasal dari tenaga orang yang } \\
& \text { penumbuk } \\
& \mathrm{A}= \text { luas silinder penumbuk (tetap) } \\
& \mathrm{H}= \text { tinggi kejatuhan penumbuk (tidak } \\
& \text { tetap, sesuai tinggi orang dalam } \\
& \text { mengayunkan palu tempa. }
\end{aligned}
$$

Dari proses inilah sangat banyak terdapat kesalahan proses pembentukan logam, jadi tidak salah kalau produk yang dihasilkan tidak sebagus produk China yang sudah menggunakan mesin tempa dalam pembuatan alat-alat pertanian.

\section{Proses Strain Hardening/Penyepuhan}

Proses ini sangat sederhana hanya memanaskan kembali produk dan didinginkan secara cepat kedalam air dingin.
Akan tetapi sama seperti sebelumnya pemanasan yang dilakukan seharusnya pada temperatur Austenit dan diukur, tetapi kenyataan hanya berdasarkan perubahan warna merah menyala saat pembakaran saja, kemudian didinginkan pada air yang tidak pernah diganti (air tertampung) sehingga kesalahan ada pda temperatur dan media pendingin. Tujuan proses ini sangat utama yaitu mengeraskan produk logam agar tahan terhadap beban kejut, benturan dan dapat dengan mudah untuk ditajamkan. Seharusnya temperatur terukur dan media pendingin harus air dingin yang bersih dengan $\mathrm{pH}$ netral. Sebab air yang tidak bersih sumber petaka pada logam yang akan mengakibatkan mudahnya logam tersebut terkorosi. Tetapi pengetahuan yang kurang membuat proses seadanya dan sebisanya saja.

\section{Proses Penggerindaan}

Penggerindaan dimaksudkan sebagai finishing untuk merapikan hasil tempa dan menajamkan produk, dimana seharusnya sebelum difinishing dengan gerinda dilakukan dulu proses Tempering dan Karburizing yang dapat meningkatkan kekuatan dan ketahanan terhadap korosi. Setelah itu baru produk digerinda untuk ditajamkan.

\section{SIMPULAN}

Dari uraian diatas, dapat disimpulkan bahwa sepinya suara dentingan palu tempa atau mulai sunyi disisir zaman dan teknologi, tentu saja disebabkan beberapa hal yang sangat-sangat logis sesuai dengan zamannya, perkembangan dunia yang mengarapkan distribusi barang dapat mudah beredar diseluruh dunia menyebabkan industri ini semakin terpinggir, ditambah lagi dengan rendahnya pengetahuan tentang logam dan proses pembentukan logam, serta masih kuatnya pengrajin memakai tradisi lama dalam pengolahan produk alat-alat pertanian. Disamping itu pengarajin juga harus menyadari bahwa kecenderungan manusia selalu menginginkan barang yang bagus dan sedapat mungkin dengan harga yang murah, untuk itu ada beberapa hal penting yang 
sangat harus diperhatikan oleh pengrajin antara lain:

1. Pemilihan material bahan baku harus selektif, dimana pengrajin harus bisa menyortir bahan yang masih layak untuk diproduksi. Pengetahuan tentang material secara visual bisa dipelajari dengan membaca beberapa ulasan tentang material pegas daun.

2. Proses pemanasan harus sesuai dengan kaidah metalurgi dimana temperatur pemanasan harus sampai pada fasa Austenit sehingga aliran logam saat pembentukan tepat, dan pembentukan logam dapat menghasilkan mekanisme rekristalisasi.

3. Proses tempa/forging sebaiknya tidak lagi manual, sebaiknya sudah menggunakan mesin walau yang sifatnya semi mekanik. Selain hasil lebih baik, tonase produk pun dapat ditingkatkan, sehingga produksi bisa cepat dan mudah.

4. Prosess Strain Hardening dilakukan dengan tepat terutama pemanasan, harus tepat serta pencelupan dilakukan pada air dingin yang bersih yang benar-benar terukur pHnya, sehingga struktur martensit yang dihasilkan tepat, sehingga kekerasan yang diharapkan pada logam dapat dicapai.

5. Pada proses finishing sebelum dilakukan proses penggerindaan sebaiknya, ditambah dengan proses temperering dan karburizing, selain menambah kekuatan logam, mengembalikan sifat-sifat fisik logam dan memberikan perlindungan ketahanan korosi terhadap produk.

6. Kami merasa perlu untuk memberikan sosialisai/penyuluhan berupa transfer IPTEK dan membuatkan perencanaan mesin-mesin penunjang produksi agar pengrajin dapat berubah menjadi pengrajin yang moderen. Dimana produksi alat-alat pertanian ini dapat dijadikan sumber pendapatan dan budaya kerajinan ini dapat dilestarikan.

\section{UCAPAN TERIMA KASIH}

Penulis ingin mengucapkan terima kasih kepada:

1. Allah SWT yang telah memberikan rahmat dan hidayahnya sehingga penulis ingin membuat perubahan untuk industri yang hampir punah ini.

2. Bapak Ir. Surya Eka Priana, MT yang bersedia membuatkan tungku pembakaran dengan kualitas campuran semen yang lebih baik.

3. Mahasiswa yang telah bersedia berpartisipasi memberikan informasi lokasi-lokasi pengrajin pandai besi, dan ikut serta dalam penelitian ini (Gimi Bayu, Sabri Kurniawan, Roni Saputra).

4. Para rekan-rekan di Kampus Hariyadi, S.Kom, M.Kom, Rudi Kurniawan Arif, ST. MT, Kevry Ramdany, A.Md, yang selalu mengingatkan untuk menulis dan menyemangati untuk selalu produktif.

5. Para Pengrajin antara lain Bapak Nasrul, dan Bapak Bandaro

\section{DAFTAR PUSTAKA}

ASTM A536, Annual Book of ASTM Standart, vol.i.02, ASTM, West Conshohocken, PA, 1999

ASTM A536, Annual Book of ASTM Standart, vol.i.02, ASTM, West Conshohocken, PA, 1999

B.H Amstead, Sriati Djaprie, Teknologi Mekanik, Edisi ketujuh jilid 1, Erlangga 1995.

Degarmo, Material and Process in Manufacturing, 7 Edition, Macmilan Publishing Company, New York, 2000.

Steel Hardening Process, http://www.roymech.co.uk/useful tabel/matter/iron steelform/2006

Fontana, M.G., 1986, Corrosion Engineering, $3^{\text {rd }}$ Edition, Mc Graw Hill, Ohio

Vlack, V., 1980, Ilmu dan Teknologi Bahan Teknik (alih bahasa: Sriati Dj), Edisi ke-4, Erlangga, Surabaya.

Smallman, R.E 1991, Metalurgi Fisik Modern (alih bahasa: Sriati Dj), Edisi ke-4, PT. Gramedia, Jakarta. 